\title{
The secular prophet of religious socialism
}

The Erich Fromm's early writings (1922-1930)

Michael Löwy*

https://orcid.org/0000-0001-5679-0927

Dialectics of the secular and the sacred

There exists a German-Jewish cultural discourse from the early 20th century that stands in dynamic tension between spiritual and material, sacred and secular, beyond the usual static dichotomies. Several key Jewish thinkers have sought to recover spiritual meaning, in direct interaction with the profane. Under different ways they developed a process of simultaneous secularization and sacralization, in a sort of "dialectic" combination of both. Among some examples: Franz Kafka, Walter Benjamin, Ernst Bloch, Erich Fromm, Gustav Landauer, Martin Buber, Gershom Scholem, Leo Löwenthal, Hans Kohn, Manes Sperber and others. This applies particularly to their early writings (until 1933) although in some cases it holds true during their entire life.

The first common characteristic of these authors is their deep attachment to the German romantic culture, with its ambivalence towards modernity, and its desperate attempt at re-enchanting the world through a return to past spiritual forms. For the Jewish thinkers, this meant a rediscovery of the spiritual treasures of the less rational and less codified forms of Jewish religiosity, the "romantic" religious traditions of the past: the Prophets, Messianism, Mysticism, Kabballah, Sabbataism, Hassidism.

* Centre National de Recherche Scientifique, Paris, França. 
However, being modern subjects, they cannot return to the faith of their ancestors: their spirituality is intimately intertwined with secular aspirations. These aspirations lead them - and this is another common aspect of their writings - to support radical social/political utopias, such as socialism, communism or anarchism, which are in a relation of elective affinity with the Jewish Messianic heritage.

In his already canonical essay $A$ Secular Age, Charles Taylor has an interesting insight: the Romantic protests against disenchantment can take both religious and secular forms. However, "in the face of the opposition between orthodoxy and unbelief, many, and among them the best and the most sensitive minds, were [...] looking for a third way" (Taylor, 2007, p. 302). Most of the Romantic Jewish-German authors above mentioned seem to be among these "best and most sensitive minds" searching for a third way.

A tentative typology of the various forms of this dialectic between secularisation and sacralisation would distinguish the following:

1. Orthodox religious socialism: Erich Fromm's doctoral thesis (1922)

2. Heterodox religious socialism: Martin Buber, Gershom Scholem, Hans Kohn and the young Leo Löwenthal. The rejection of assimilation, and the assertion of a strong but heterodox religious Jewish identity, is the dominant aspect of their thought. And all share, on various degrees, a universal utopian perspective, a sort of libertarian (Anarchist) socialism, which they articulate with their Messianic religious faith.

3. Revolutionary (Jewish) messianism: Walter Benjamin. The religious/profane connection takes here the form of what Benjamin once called, in a letter to Scholem, from May 1926, the "paradoxical mutual reversal (Umschlagen) of the religious into the political". Concerning his last writing, the Thesis On the concept of history (1940), one could say that revolution and messianism enter in a relation of correspondence (in the sense Baudelaire uses the term).

4. Secular religion of liberty: Franz Kafka. In a letter to Grete Bloch from June 1914 Kafka insisted that he was a "non believing" Jew. However, there appears in his writings something which could be described as a secular/sacred "Religion of Liberty", where absolut individual freedom becomes a messianic principle.

5. Religious atheism, Secular Jews, with religious interests and Anarchist or Marxist sympathies: Gustav Landauer, Ernst Bloch, the young Georg Lukács, Manès Sperber. Religious atheism is a paradoxical figure of the spirit that seems to deny traditional religious beliefs ("God") in order best to appropriate, with a deep emotional intensity, religious ideas and symbols. 
Let us briefly discuss the case of Erich Fromm (1900-1980) whose early writings present a unique combination of orthodox Judaism and radical socialist ideas, religious beliefs and secular science: Weberian sociology first, Freudian psychoanalysis next, and finally Freudo-Marxist historiography.

Fromm is well known for his essays in social psychology, most of them written after his exile in the United States at the end of the 1930's. But his less known early works - from 1922 to 1930 - are very creative, as well as politically radical, and deserve to be discussed. They have some common aspects: a messianic understanding of Judaism; a socialist rejection of capitalism as a socio-economic system; and the revolutionary aspiration for a social utopia with religious roots. These elements together shaped an original and subversive thought.

After participating, with Martin Buber and Franz Rosenzweig, at the foundation of the Free House for Jewish Studies in Frankfurt, the young Fromm - at that time still a believing Jew - presented in 1922 at the University of Heidelberg his doctoral thesis, directed by the sociologist Alfred Weber, under the title The Jewish Law: Contribution to the sociology of diaspora Judaïsm. Probably for personal reasons - his loss of faith a few years later - the book will not be published during his life time; it will appear only 70 years later, after his death, in an edition of his complete works.

In spite of the title, the work has not much in common with a sociological monography on the diaspora Jewish communities (demography, institutions, family). It belongs rather to the classical school of the German sociology of culture and religion, as practiced by the Weber brothers, Alfred and Max. In other words, at the center of the research are the relations between socio-religious cultures and economic ethics. To these methodological references one has to add other ingredients, less conventional and less academic: the ideas of his master in Talmud, Rabbi Salman Baruch Rabinkow, partisan of a socialist Judaïsm influenced by the Russian intelligentsia, and of Martin Buber, the romantic socialist who re-discovered Hassidism. The most astonishing aspect of this doctoral thesis is its strong anticapitalist and anti-bourgeois edge, which seems to belong to the realm of Jewish religious socialism ${ }^{1}$.

1. One can find in Lawrence J. Friedman's intellectual biography of Erich Fromm a very lively presentation of the early religious studies and activities of Fromm, as well as of his relation to Rabinkow, Buber, Rosenzweig and others. However, when discussing Fromm's doctoral thesis he missed the strong sociopolitical message of the work. See Friedman (2013, pp. 3-28). 
The first chapter, “The significance of Law in Judaïsm”, is an attempt at a socioreligious analysis of the Jewish religion inspired by Alfred Weber's sociology of culture $^{2}$. According to Fromm, the loss of State, language and territory did not prevent diaspora Judaism from keeping its social and religious identity. By destroying Judea, the Romains only dealt with a shell (Gebäuse), without importance for the Jewish historical body. There is probably a sort of Anarchist tendency in this negative attitude towards the State. In Fromm's understanding, Jewish religion, which assured the continuity of the Jewish people in the diaspora, was not a theological system, a body of dogmas, but a collection of laws and rules, the Halacha, which did not manifest itself so much in the Kindgon of Ideas, but rather in "value-rational actions (wertrationalen Handeln) of Max Weber" (Fromm, 1989, pp. 16-21). This first chapter includes an interesting section called "Labor and Vocation (Beruf) in Rabbinical Judaism"; directly inspired by Max Weber, Fromm tries to demonstrate that, unlike Protestant ethics, the Jewish ones are not favorable to the spirit of capitalism. Jewish economic ethics are, in Weber's terminology, "traditionalist”: knowledge, not labor, is the supreme value; not by accident, in the Biblical narrative of the expulsion from Paradise, work is presented as a malediction. Alternating Biblical, Talmudic and... Weberian quotations, Fromm argues that "in direct contradiction to the Puritan conceptions", Jewish ethics do not at all consider the acquisition of wealth as a duty towards God; they represent, therefore "a non-capitalist attitude towards the economy”. For sure, one can find, in modern times, Jewish capitalists, but, as Weber has shown, this is a "pariah capitalism", speculative, political and adventurous, in contrast to the Puritan ethos of the rational bourgeois enterprise, with its rational organization of labor (Fromm, 1989, pp. 41-54).

Fromm rejects - again, referring himself to Max Weber - Werner Sombart's attempt to present the Jews as the first modern capitalists, and his definition of Judaism as a purely rationalist religion: the ethical line which goes from the biblical Prophets until Hassidism, passing by the Mishna and the Kabbala, is anything but rationalist. The $19^{\text {th }}$ century German rabbis quoted by Sombart in support of his thesis do not represent the authentic Jewish religion - which remained alive among the Jewish masses of Eastern Europe - but rather the modern "capitalist culture" (Fromm, 1989, pp. 41-54).

The chapter called "Reform Judaïsm" is precisely a critique of the currents which attempted to re-elaborate the tradition, from Moses Mendelssohn, at the end of the 18 the century, to the Reform Judaism of the $19^{\text {th }}$ century. The reformers - which 
include for Fromm not only Abraham Geiger, founder of the enlightened Wissenchaft des Judentums, but even Raphael Samson Hirsch, the initiator of a would-be neo-orthodox movement! - tried to adapt Judaism to the requirements of the new times, and to the needs of the German bourgeois society: they wanted to reconcile the ethics of Judaism with the spirit of capitalism, at the price of sacrificing the laws and moral principles of historical Judaism. Reform Judaism, adopted by the capitalist/bourgeois social layers, led therefore to the dissolution of the Jewish « popular body » (Volkskörper), rendering the Jewish law, the unifying element of this body, useless and superfluous (Fromm, 1989, pp. 121-155). Obviously this violent attack on Reform and liberal Judaism went against the grain of the dominant Jewish opinion in Germany.

The last chapter of the book is devoted to Hassidism, which Fromm defines as a "social-religious movement of self-emancipation", radically opposed to the bourgeois/ capitalist spirit. By its radical democratism, its mysticism of community, it represents a "social-religious revolutionary principle". Finally, by its joyous and anti-ascetic spirit, its practice of fraternity and mutual help, and by its traditionalist economic frame of mind (Gesinnung), Hassidism develops an "entirely anti-capitalist attitude" (Fromm, 1989, pp. 161-184).

The orthodox rabbinical circles, who refused to join Hassidism - known as the Mitnagdim (in hebrew: "the Oponents") - had, in contrast, ascetical practices which remind those of the Protestant Puritan sects described by Max Weber. This explains, concludes Fromm, why German Judaism, hostile to Hassidism, could so easily be won by the spirit of capitalism.

After discussing also Karaism - a "heretical” Jewish current founded by Anan Ben David on the 8th Century, which developed mainly in the Muslim world - Fromm compares the historical significances of the two great socio-religious movements of modern Judaism: Hassidism, who refused any change in the religious tradition aiming to satisfy economic requirements, and Reform, who led to the triumph of the spirit of capitalism over the spirit of Judaism.

What is striking in this essay - obviously written by a believing Jew, attached to the spirit and the letter of the Law - is not only the strongly idealized vision of Hassidism, and the equally one-sided demonization of Reform Judaism, but above all the emphasis on the opposition between the Jewish tradition and capitalism, with frequent references to Max Weber's writings. Erich Fromm belongs, like Buber and others, to the religious romantic anti-capitalist - not Marxist - current, well represented among the Central-European Jewish intelligentsia. More specifically, he belongs, like Walter Benjamin, Ernst Bloch, and others, to a group that developed "anti-capitalist interpretations" of Max Weber, quite opposed to the non-committed 
- "free of value-judgements" (Werfrei) - attitude of the author of The Protestant Ethic and the Spirit of Capitalism ${ }^{3}$. In any case, Fromm's Thesis is the only systematic attempt to study the tensions between the Jewish ethic and the modern (capitalist) economic sphere, using Max Weber's method in his essay on The economic ethics of words religions.

In 1923, Erich Fromm settled in Heidelberg, where he was psychoanalyzed by Frieda Reichmann, an orthodox Freudian with whom he fell in love and married in 1926. It was probably the impact of his analysis that made him loose his religious faith - even if his thinking remained always deeply tinged with religiosity. Freud and soon later Marx became the guiding lights of his work.

In 1927, Fromm published his first psychoanalytical work, in Imago, Zeitschrift fur Anwendung der Psychoanalyis auf die Natur und Geisteswissenschaften (Journal for the application of psychoanalysis to the sciences of nature and of the spirit) edited by Sigmund Freud. The issue had a common theme, "Faith and Custom" (Glaube und Brauch); it included an article by Frieda Fromm-Reichmann of "The Jewish culinary ritual", as well as, among others (Jones, Reik, Roheim), an essay by Freud himself, "Complement to the work on Michelangelo's Moses".

Discussing the writings of Freud on the Oedipus-complex, Otto Rank on the trauma of birth, as well as Theodor Reik and Karl Abraham on the psychoanalysis of religion, Fromm's article bears witness to his assimilation of the Freudian theory; but it also documents his persistent interest in Jewish religion... The article, Der Sabbath, is a quite astonishing piece with a powerful messianic impetus, in spite of its scientific psychoanalythical language.

What is the meaning, asks Fromm, of the interdiction of work during the Jewish Sabbath? Labor meant, for the ancient Jews, the intervention on nature, more specifically, for an agrarian people, the belaboring of earth. The Sabbath is therefore a suspension of Man's incestuous violation of Mother Earth. By strictly and harshly prohibiting any form of labor during the Sabbath, Jewish religion sought the reestablishment (Wiederberstellung) of the paradisiacal state of humanity: without work and in harmony with nature. This is why the Talmud tells us that the Messiah will come only if the people of Israel integrally keeps, at least once, the Sabbat. According to Fromm,

The prophets regarded messianic time as a condition in which the struggle between man and nature would reach an end [...] If man was expelled from Paradise because he wanted

3. It is interesting that neither Marx not any Marxist authors are mentioned in Fromm's thesis, not even in the bibliography. 
to be like God - that is, the father's equal, capable of conquering the mother - and if work was punishment for that primal breach (Urverbrechen), then, according to the prophets, in the messianic period human beings would live once more in complete harmony with nature, in other words, without having to work, in Paradise - the equivalent of the mother's womb (Fromm, 1927, pp. 226-233).

This is the reason, argues Fromm, why the Sabbath, in spite of its ascetic moments, is above all, "thanks to the rabbinical association of the messianic and the sabbatical time', a joyful celebration, with a deep "instinct-satisfying tendency" (triebbefriedigende Tendenz). The legitimate heir to this tradition is the Hassidic movement, for whom the Jewish Sabbath is the expression of a "jubilant instinct-affirmative feeling" (triebbejabend Stimmung). The opposite of this is the Puritanic Sunday, which has an entirely somber and ascetic character (Fromm, 1927, p. 234). Translated into Freudian language, we find the same argument in praise of Hassidism, and in rejection of Puritanism, that Fromm developed in his doctoral thesis.

This piece was considered by Fromm's friends as a sort of public break with Jewish religious orthodoxy (Friedman, 2013, p. 22) ${ }^{4}$. At first sight it is indeed a purely secular piece, a contribution to the psychoanalytical study of myths and religions; otherwise Sigmund Freud would not have accepted to publish it in the official journal of his movement! It is also an apology for the social, ethical and - surprisingly enough - ecological significance of the Jewish Shabbat. The word "ecology" was not used at that time, but there was, for instance in various Jewish and non-Jewish youth movements, a strong desire to "Return to Nature". Erich Fromm is certainly inspired by this romantic "naturalism", but his argument is more radical, challenging the idea itself of a "struggle with nature". Once more, like in his doctoral thesis, Jewish religion is being opposed to the Protestant ethic of labor, but this time with a specific Freudian argument. It is interesting that Fromm's romantic socialism goes here against the grain of the dominant tendency in the socialist labor movement, who had a positive view of work and of the "conquest of nature". A few years later, in the 1930's, Walter Benjamin will develop a thorough criticism of this dominant view.

But is Fromm's article a purely secular document? The innumerous quotation from the Shulchan Aroch, the legitimation of the "harsh and strict" - i.e. Orthodox - interdictions of labor during the Sabbath, and the emphatic references to the Hebrew prophets, to the Talmud, and to the Messianic promise of a return to the Lost Paradise, give to the essay a distinct religious flavor. Obviously Fromm had distanced himself

4. .Curiously enough Friedman does not discuss at all the content of Fromm's article, just mentioned in a footnote. 
from Jewish Orthodoxy but the Imago article, with it's striking messianic/utopian horizon, is still deeply rooted in the symbolic and ethical religious universe.

There are some interesting similarities between Fromm's article and a piece on "Kabbala" that Scholem published a few years later (1932) in the Encyclopaedia Judaica: both emphasize the messianic idea of a re-establishment of the Lost Paradise. According to Scholem, the kabbalist writings affirm that Adam's sin can be erased only through messianic Redemption. In the messianic "World of Tikkun", all things will return to their initial place, in Hebrew: ha-Shavat Kol ha-Dvarim le-Havaiatam. (Scholem, 1932, pp. 659-663). It is probable that Scholem knew Fromm's article they had been close friends in the early 20's - but it is rather unlikely that he was influenced by him. The analogy only documents common interests among JewishGerman intellectuals with a romantic/religious background.

During the late 1920's Fromm will become increasingly interested in marxism; he meets freudian-marxists such as Wilhelm Reich and Siegfried Bernstein, and he establishes close links with the marxists of the Frankfurt School, such as Leo Löwenthal and Max Horkheimer. In 1930 he is appointed by Max Horkheimer - the head of the Institute for Social Research (the Frankfurt School) - director of the Social Psychology Section of the I.SR. Fromm's attempt to combine marxism and freudism lies at the heart of his works in the following years. His first major work in this field - published as a large essay in Freud's journal Imago and then as a book was the essay The Dogma of Christ (1931): this new interest in the Evangiles is not at variance with his previous Jewish concerns, since he considers early Christianity as the direct successor of Jewish Messianism struggling against the Roman empire. However, this writing is, unlike the previous ones, entirely of a secular character.

One cannot understand Christianity, argues Fromm, without taking into account the social-historical conditions of its appearance. In order to give a brief overview of the economic, social, cultural and psychical situation of the first Christians, he will borrow from Eduard Meyer's book on ancient slavery, on Max Weber's essay on the social foundations of the decline of ancient civilisations, and on Karl Kautsky's book on the origins of Christianity.

In Fromm's view, Christianity was originally “a messianic revolutionary movement", bearing the message of eschatological expectation, the imminence of the Kingdom of God. The early Christian community was "a free brotherhood of the poor", intensely hostile to all authority or "paternal" power. The original Christian myth depicted Christ as the suffering Messiah who was elevated to the dignity of God; it bore a concealed hostility to God the Father, the Emperor and authority in general. Christianity was the expression of the revolutionary tendencies, the expectations and longings of the oppressed masses - first Jewish and then gentile - who grouped 
together in a "community organization without authorities, statuses or bureaucracy", based on economic mutual help, and love communism, a concept proposed by Adolf von Harnack and adopted by Max Weber (Fromm, 1963, pp. 35-49).

From the third century on, however, the social foundations of Christianity were transformed, when it became the religion of the upper classes of the Roman Empire. The eschatological hope for real historical deliverance was gradually replaced by the idea that salvation would be an internal, spiritual, non-historical and individual liberation. Finally, in close association with this disavowal of Messianism, a growing reconciliation took place between Church and State. In other words, "Christianity, which had been the religion of a community of equal brothers, without hierarchy or bureaucracy, became 'the Church', the reflected image of the absolute monarchy of the Roman Empire". Together with this transformation of a free confraternity into an authoritarian, hierarchical organization, there was also a psychic change: hostility towards the father, and the early Christian contempt for the rich and the powerful, for all authority, was replaced by reverence and subordination to the new clerical authorities. Aggressive impulses, originally directed against the father, where then turned against the self in a manner that posed no danger for social stability; they thereby induced a general feeling of guilt - along with a masochistic need for atonement (Fromm, 1963, pp. 56-65).

The Dogma of Christ owes much to Theodor Reik's essay "Dogma and Compulsion" (1927), which had already suggested the interpretation of the primitive Christian faith as the expression of hostility to the Father. The difference between both is precisely the social-historical dimension. According to Fromm, Reik's mistake was to neglect the diversity of social and psychical interests of social groups: the different dogmas are the expression of social conflicts, and the triumph of a dogma against others is not the result of a purely internal psychic conflict like in an individual, but of historical developments that lead to the victory of one side and the defeat of the other (Fromm, 1963, p. 85).

The Dogma of Christ was hailed by Franz Borkenau in the Zeitschrift für Sozialforschung - the Journal of the Institute for Social Research - as the first concrete example of a synthesis between Freud and Marx (Jay, 1973, p. 91). What is striking about his interpretation of marxism and freudianism is its strong anti-authoritarian, anti-bureaucratic, revolutionary orientation. The book is both a scholarly research in Church history and theological theory, and a powerful political statement. Could it be that his presentation of the history of early Christianity as the transformation of a free confraternity into an authoritarian, hierarchical organization is an implicit reference to the disappointing evolution of the Soviet Union under Joseph Stalin, during the 1920's? The frequent use of the term "bureaucratic" seems to hint at 
such an historical parallel. The question remains open, but it is clear that Fromm's own political views in 1930 are an important background for his study of early Christian dogmas.

\section{Bibliography}

Friedman, L. J. (2013), The lives of Erich Fromm, love's prophet. New York, Columbia University Press.

Fromm, E. (1927), “Der Sabbath”, Imago, Zeitschrfit fur Anwendung der Psychoanalyse auf die Natur und Geisteswissenchaften, vol. XIII, Vienna, Internationaler Psychoanalytischer Verlag. Fromm, E. (1963), The dogma of Christ and other essays on religion, psychology and culture. New York, Holt, Rhinehart/Winston, pp. 35-49.

Fromm, E. (1989), Das judische Gesetz: Zur Soziologie des Diaspora Judentums. Basel, Beltz: Ranier Funk and Bernd Sahrler.

JAY, M. (1973), The dialectical imagination: A history of the Frankfurt School and the Institute of Social Research. Boston, Little Brown and Company.

Scholem, G. (1932), Kabbalah. Encyclopaedia Judaica, vol. 9. Berlin.

TAYlor, C. (2007), A Secular Age. Cambridge, Harvard University Press.

\section{Abstract}

The secular prophet of religious socialism: The Erich Fromm's early writings (1922-1930)

There exists a German-Jewish cultural discourse from the early $20^{\text {th }}$ century that stands in dynamic tension between spiritual and material, sacred and secular, beyond the usual static dichotomies. Several key Jewish thinkers have sought to recover spiritual meaning, in direct interaction with the profane. Under different ways they developed a process of simultaneous secularization and sacralization, in a sort of "dialectic" combination of both. The first common characteristic of these authors is their deep attachment to the German romantic culture, with its ambivalence towards modernity, and its desperate attempt at re-enchanting the world through a return to past spiritual forms. This article will demonstrate these relationships through the work of young Eric Fromm. Keywords: Marxism; Freudism; German romanticism; Religion.

\section{Resumo}

O profeta secular do socialismo religioso: os primeiros escritos (1922-1930) de Erich Fromm

Há uma produção cultural germano-judaica do início do século Xx que se encontra em tensão dinâmica entre elementos espirituais e material, sagrado e secular, para além das habituais dicotomias estáticas. Vários pensadores importantes de origem judaica dessa fase têm buscado recuperar o sentido espiritual e sua interação direta com as questões do profano. Sob diferentes formas eles desenvolveram um processo de secularização e sacralização simultânea, numa espécie de com- 
binação "dialética" de ambas. A primeira característica comum desses autores é o seu profundo apego à cultura romântica alemã, com sua ambivalência em relação à modernidade, e sua tentativa desesperada de reencantar o mundo através de um retorno às formas espirituais do passado. Este artigo procura demonstrar essas relações através das obras de juventude de Eric Fromm.

Palavras-chave: Marxismo; Freudismo; Romantismo Alemão; Religião.

Texto recebido em 10/4/2020 e aprovado em 20/4/2020.

DOI: 10.11606/0103-2070.ts.2020.168672.

Michael Löwy é doutor em ciências sociais e diretor de pesquisa do Centre National de Recherche Scientifique, CNRs. E-mail: michael.lowy1@gmail.com. 